\title{
Effect of intercropping soybean with sorghum on yield and its components of the two crops
}

\author{
Gadallah, R.A. and S.b.Ragheb*
}

\author{
Crop Intensification Research Department* Food Legume Res. Dept., Field Crop Research Institute, \\ Agricultural Research Center, Giza, Egypt
}

\begin{abstract}
A field trial was conducted at Sids Agricultural Research Station., Beni-Sweif Governorate during the summer of season 2010 and 2011 to evaluate the effect of intercropping of soybean with sorghum of different patterns on yield and its components of the two crops. A split plot design with three replications, where main plots contained three intercropping patterns $\left(\mathrm{P}_{1}\right) \quad 100 \%$ sorghum $+25 \%$ soybean, $\left(\mathrm{P}_{2}\right) \quad 100 \%$ sorghum $+50 \%$ soybean and $\left(\mathrm{P}_{3}\right) 100 \%$ sorghum $+75 \%$ soybean. However sub plot comprised Giza 35, Giza 83 and Giza 111 soybean cultivars.

The results indicated that sorghum yield/fad. Gave the highest at $100 \%$ sorghum $+25 \%$ soybean cultivars Giza 83 it was decreased with increasing soybean percentage. Seed yield/fad. of soybean was higher when Giza 111 cultivar at $75 \%$ intercropped to sorghum compared with Giza 35 and Giza 83 cultivars.

The highest land equivalent ratios (LER) were 1.55 and 1.56 while land equivalent coefficient (LEC) were 0.59 and 0.60 when intercropping patterns $(100 \%$ sorghum $+75 \%$ Giza 111 soybean cultivar) in the first and the second seasons, respectively. The aggressivity (Agg) of soybean was dominant while sorghum was dominated at ( $100 \%$ sorghum $+75 \%$ soybean cultivar). The greater values competitive ratio (CR) of soybean were 1.18 and 1.05 while sorghum were 1.11 and 1.16 when intercropping patterns $(100 \%$ sorghum $+25 \%$ soybean Giza 35 cultivar and $75 \%$ soybean Giza 111 cultivar

The highest values monetary advantage index (MAI) were 1982.74 and 2509.07 while the highest monetary advantage ratio (MER) were 1.47 was 1.52 when observed intercrop (100\% sorghum + 75\% soybean Giza 111 cultivar in the first and the second seasons, respectively.
\end{abstract}

Keyword: Intercropping patterns, sorghum, soybean, competitive relationships.

\section{Introduction}

Multiple cropping plays an important role in agriculture because of the effective utilization of resources, significantly enhancing crop productivity compared with that of monoculture crops (Li et al 1999).

In the intercrop the degree of resource complementarily, the total yield and the participation of yield between the individual species is determined by both inter and intra specific competition, which again is influenced by the availability of environmental resources, the relative frequency of the species and the density of components Haugguard et al (2001). Cereals deplete soil nitrogen and produce carbohydrates while legumes fix atmospheric nitrogen and produce protein. The cereal legumes mixture improves the diet of tropical farmers as well as the soil of their farms (Tariah and Wahua 1985).

Grain sorghum (Sorghum bicolor L. Moench) grows in about 0.390 million faddan is concentrated mainly at Middle and Upper Egypt and preceded by either legumes or non legumes winter crops, so it ranks the fourth among cereal crops after wheat, rice and maize in terms of acreage and production. It is usually used for both food and feed over the world including Egypt, where the cereal national production suffers large gap with the total consumption of the explosive population. Despite of the moderate tolerance of sorghum plants to drought and salinity, the old leaves display marked senescence in its cultivated area. This phenomenon encourages farmers to defoliate old leaves as feed for their animals.

Soybean (Glycine max Merr.) is the most important grain legume crop in the world in terms of total production international trade. Soybean seed contain from protein and oil. Soybean area in Egypt has been dramatically decreased as a result of severe competition from strategic summer crops.

Soybean is considered a crop of enormous potential for improving human diet as well as animal feed and features prominently as row material base for ago-industries.

Aggarwal et al (1992) reported that the yield advantage of any intercrop is attributed to below and above-ground plant interactions which are likely to vary depending upon the temporal spatial difference in resource use by components crops.

Spitters (1983) reported that yield of grain per unit area is an essential measure of mixture performance which represent only a part of total plant biomass and may not fully reflect the result of competition between species in mixture. A number of indices such as land equivalent ratio, relative 
crowding coefficient, competitive ratio, actual yield loss, monetary advantage and intercropping advantage have been proposed to describe competition within and economic advantage of intercropping systems (Banik et al 2000).

Cereal/legume intercropping increase dry matter production and grain yield more than their monocultures. In developing countries, intensification of agricultural systems will result in greater production and income per unit area/year. Multiple cropping systems (sequential cropping and intercropping) may be one of the most important means for intensifying the agricultural system. The growth of the two crops together in the same field during a growing season may result in inter specific competition or facilitation between the plants (Zhang and Li 2003). Thus, the overall mixture densities and the relative proportion of component crops are important in determining yields and production efficiency of cereal-legume intercrop systems (Willey and Osiru, 1972).

The advantage of intercropping over sole cropping is that competition for resources between species are less than within the same specifics. In tropical agriculture, for example, tall and short crops are grown together to maximize production. Singh and balyan (2000) indicated that the intercropping systems registered significant increase in total productivity (sorghum equivalent) over sole sorghum.

Abdur Rashid et al (2004) reported that more over planting pattern and legumes intercropping had significantly affected the number of grain panicle of sorghum. The grain yield of sole sorghum was significantly more than the grain yield of sorghum associated with many bean or guar.

El-Naim et al (2013) indicated that yield significantly differences among the spatial arrangements 1:1 arrangement obtained the highest values of sorghum panicle weight, and sorghum grain yield for both sorghum and cowpea whereas the total LER was (2.11) Rees et al (1998) It has also been both maize and sorghum are always given priority over other crops through timely planting and/or cropping area size.

Langat et al (2006) reported that intercropping significantly affected the yield component of sorghum number of tiller and viable panicles per plant were generally higher in intercrops than in pure stands.

Wahua and Miller (1978 a, 1978 b) indicated that short sorghum grown with soybean had lower grains/ head than its monoculture. Soybean yields with short and tall sorghum were reduced by 18 and $16 \%$ respectively, from monoculture yield.

Abou Keriasha et al (1993) reported that the highest value of seed yield of soybean was obtained by intercropping soybean with short sorghum. Intercrop sorghum had greater weight of grain/head and 100 grain weight, than pure stand. Land
Equivalent Ratio (LER) was greater with short sorghum. Aggressivity (Agg) values were positive for sorghum while aggressivity values of soybean were negative.

Many studies of cereal/legume intercropping have shown that the quantity of $\mathrm{N}$ fixed by the legume depends on such factors the morphology, density and competitive ability of the legume (Ofori and Stern 1987)

Olowe et al (2006) showed that intercropping soybean into sunflower significantly reduced its grain yield by $67-98 \%$ relative to its sole.

Yilmaz et al (2007) showed that maize, sorghum or millet grain yields were increased or slightly affected by intercropping system compared with the sole crop, but that of legume crop yields (cowpea and bean) showed decrement 50\%.

Oseni (2010) indicated that grain and straw yields of both sorghum and cowpea were higher in sole cropping than in the intercropping mixture.

Ahmad et al (2010) found that intercropping can increase light interception and increased shading in intercropping system compared to sole maize and reduce water evaporation and improve conservation of soil moisture. Based on high grain and suitable envirmental condition intercrop productivity compared to sole crop could be selected for improving the productivity of maize and cowpea.

Barik et al (1998) reported that sorghum + groundnut gave the highest LER, monetary advantage and relative net return.

Ghosh (2004) Further explained that because of the difference in canopy height of soybean and sorghum, the two species not only competed for nutrient water but also for sunlight.

Ghosh et al (2006) observed that yield and land equivalent ratio (LER) of both the intercrops increased over sole crops through based on aggressivity and relative crowding coefficient (Rcc) sorghum (+) is more competitive than soybean.

Elmore and Jackobs (1984) intercropped soybean yields were greater with short than with tall sorghum cultivar. Impotents contributing to their greater yields were greater pods/plant, seeds/pod and seed weight.

The aim of this study is to increase the area planted to soybean in areas of sorghum at Middle and Upper Egypt.

\section{Materials and methods}

A field trial was conducted at Sids, Experimental Station Beni-Sweif Governorate during 2010 and 2011 to evaluate intercropping of three soybean cultivars with sorghum under different patterns on yield and its components of the two crops.

The experimental design was split plots design with three replicates, the plot area was $16.8 \mathrm{~m}^{2}$ consisting of 8 ridges $0.60 \mathrm{~m}$ width and $3.5 \mathrm{~m}$ length. The main 
plots contain three intercropping patterns. $\left(\mathrm{P}_{1}\right)$ sorghum intercrop was planted in the whole plot (8 ridges) in hills $30 \mathrm{~cm}$ apart and 3 plants/hill, while soybean was planted on two ridges number 1 and 8 to give $(100 \%$ sorghum $+25 \%$ soybean $),\left(\mathrm{P}_{2}\right)$ soybean was planted on four ridges number $1,3,6$ and 8 to give (100\% sorghum $+50 \%$ soybean) and $\left(\mathrm{P}_{3}\right)$ soybean was planted on six ridges number 1,2 , $3,6,7$ and 8 at the other side of sorghum ridges in all intercropping patterns to give $(100 \%$ sorghum $+75 \%$ soybean). Soybean intercrop was planted at $10 \mathrm{~cm}$ apart in hills and leaving 2 plants/hill. The sub-plot comprised three soybean cultivars: Giza 35, Giza 83, and Giza 111 received from the Food Legumes Research Department, Field Crop Research Institute, ARC, Giza, while sorghum cultivar Dorado was used.

The solid sorghum was planted in hills $20 \mathrm{~cm}$ apart and leaving 2 plants/hill and solid soybean was planted in hills $20 \mathrm{~cm}$ apart and leaving 2 plants/hill and planted on the two sides of ridges. Sorghum grains were sown on $20^{\text {th }}$ and $25^{\text {th }}$ May at 2010 and 2011, respectively. While planting soybean was before sorghum two weeks. Soybean was sown on $5^{\text {th }}$ and $10^{\text {th }}$ May in the first and the second seasons, respectively.

Calcium superphosphate at the rate was $30 \mathrm{~kg}$ $\mathrm{P}_{2} \mathrm{O}_{5} /$ fad. (15.5\% $\left.\mathrm{P}_{2} \mathrm{O}_{5}\right)$ was added during soil preparation. Nitrogen fertilizer of sorghum was $80 \mathrm{~kg}$ $\mathrm{N} / \mathrm{fad}$. in the form of ammonium nitrate $(33.5 \% \mathrm{~N})$ three equal doses were added every 15 days the first one was added after thinning (20 days after sowing). Potassium fertilizer was $24 \mathrm{~kg} \mathrm{~K}_{2} \mathrm{O} /$ fad. potassium sulphate $\left(48 \% \mathrm{~K}_{2} \mathrm{O}\right)$ divided into two equal doses the first dose was added immediately after thinning and the second after 15 days later. Soybean cultivars seeds were inoculated with specific bacteria (Bradyrhizobium japonicum L.) at sowing time.

Data recorded on sorghum: plant height $(\mathrm{cm})$, panicle length $(\mathrm{cm})$, head weight $(\mathrm{g})$, grain weight head $(\mathrm{g}), 100$ grain weight $(\mathrm{g})$ and grain yield/fad (ardab).

Soybean: the data for number of days from sowing to flowering and maturity were recorded on plot basis. Ten guarded plants were randomly taken from each plot to measure plant height $(\mathrm{cm})$, numbers of branches, pods and seeds/plant, seed yield/plant (g), 100 seeds weight $(\mathrm{g})$. Seed yield $\mathrm{kg} / \mathrm{fad}$. was determined from 8 ridges, area of 16.8 $\mathrm{m}^{2}$ in each plot.

\section{Competitive relationships}

1. Land equivalent ratio (LER): according to Willey \& Osiru, 1972).

$\mathbf{L E R}=\left(\mathrm{Y}_{\mathrm{ab}} / \mathrm{Y}_{\mathrm{aa}}\right)+\left(\mathrm{Y}_{\mathrm{ba}} / \mathrm{Y}_{\mathrm{bb}}\right)$

\section{Aggressivity (Agg).}

This was proposed by Mc-Gillichrist (1965) and was determined according to the following formula:
$\mathrm{Ag}_{\mathrm{a}}=\left[\mathrm{Y}_{\mathrm{ab}} /\left(\mathrm{Y}_{\mathrm{aa}} \times \mathrm{Z}_{\mathrm{ab}}\right)\right]-\left[\mathrm{Y}_{\mathrm{ba}} /\left(\mathrm{Y}_{\mathrm{bb}} \times \mathrm{Z}_{\mathrm{ba}}\right)\right] \quad \mathrm{Ag}_{\mathrm{b}}=$

$\left[\mathrm{Y}_{\mathrm{ba}} /\left(\mathrm{Y}_{\mathrm{bb}} \times \mathrm{Z}_{\mathrm{ba}}\right)\right]-\left[\mathrm{Y}_{\mathrm{ab}} /\left(\mathrm{Y}_{\mathrm{aa}} \times \mathrm{Z}_{\mathrm{ab}}\right)\right]$

An aggressivity value of zero indicates that the intercropped crops are equally competitive for any other situation both crops will have the same numerical value, but the sign of the dominant crop is positive and the dominated is negative.

\section{Competitive ratio (CR) by Willey and Rao} (1980).

$$
\begin{gathered}
\text { CRa }=\left\{\left(\frac{L E R a}{L E R b}\right) \times\left(\frac{Z b a}{Z a b}\right)\right\}, \\
\mathrm{CRb}=\left\{\left(\frac{L E R b}{L E R a}\right) \times\left(\frac{Z a b}{Z b a}\right)\right\}
\end{gathered}
$$

\section{Land equivalent coefficient (LEC)}

$$
\begin{array}{ll}
\text { crop } & \text { Lb }=\text { LER of intercrop } \\
\text { (LEC) however, measures acceptable level }
\end{array}
$$
competitive interaction confers sufficient degree of complementarily (i-e it indicates the minimum level of reasonable contribution by the least productive intercrop component) if a yield advantage is indicated Adetiloye et al, (1983). For a two crop mixture the minimum expected productivity coefficient (PC) is 0.25 i-e a yield advantage is obtained if (LEC) value exceed 0.25 .

\section{Economic evaluation:}

Monetary advantage index (MAI): Suggests that the economic assessment should be in terms of the value of land saved; this could probably be most assessed on the basis of the rentable value of this land. MAI was calculated according to the formula, suggested by Willey (1979).

\section{MAI}

$$
=\frac{\text { Value of combined intercrops } \times \mathrm{LER}-1}{L E R}
$$

6. Monetary Equivalent Ratio (MER): MER was calculated according to the formula, suggested by Adetiloye and Adekunle (1989).

Whereas:

$$
\text { MER }=\frac{\mathrm{ra}+\mathrm{rb}}{\mathrm{Ra}}
$$

ra \& rb monetary returns from (a) and (b)

$\mathrm{Ra}$. highest sole crop monetary return

$$
\begin{array}{lr}
\mathrm{ra}=\mathrm{pa} \times \mathrm{ya} & \mathrm{rb}=\mathrm{pb} \times \mathrm{yb} \\
\text { ya \& yb yield of } \mathrm{a} \text { and } \mathrm{b} & \mathrm{pa}, \mathrm{pb} \text { prices }
\end{array}
$$

of unit weight of crop $a$ and $b$

\section{Gross return (LE/fad):}

Gross return from each treatment was calculated in Egyptian pounds (LE) at market prices which were 205 or $265 \mathrm{LE}$ for grain sorghum ardab/fad. and 2207 or 2316 LE for seed soybean ton/fad. in 2010 and 2011 seasons, respectively. 
Data for each experiment were then analyzed by MSTATC (1980) software for comparison of the mean values of the two seasons by LSD test at the $5 \%$ level. Response equations were calculated according to Snedecor and Cochran (1988).

\section{Results and Discussion}

\section{Sorghum}

a. Effect of intercropping patterns of soybean cultivar on yield and yield components of sorghum.

Results in (Table 1) indicated that yield and yield components of sorghum were significantly decreased by decreasing soybean density from $75 \%$, $50 \%$ and $25 \%$, respectively. Most of yield attributes i-e panicle length, weight head, weight of grains head, weight of 100 grain and grain yield/fad. were significantly decreased by increasing density of soybean from $25 \%, 50 \%$ up to $75 \%$. These results heaved opposite trend of plant height in both seasons. These results intercropping soybean with sorghum at $25 \%$ gave the highest values character of sorghum and the lowest values was showed when soybean was planted $75 \%$ in both seasons. These results may be due to increase the shading of soybean plants which replicated to increased inter-competition between soybean and shorter sorghum plants for lights. These results are agreed with those obtained by Abdur Rashid et al (2004), Langat et al (2006) fond that the intercropped pattern with the most tiller and viable panicles per plant. This could be due to a wider inter-row and intra-row spacing between any 2 sorghum plants since sorghum rots extract moisture from a deeper soil horizon than groundnut, sorghum plants had a wider area to derive water and nutrients this treatment than sorghum in both sole and the other intercrop treatments. There was little difference in 1000-grains weight between the treatments. Eybe (2010) found that the highest grain yield sorghum with groundnut (2:2 patterns)

Sorghum yield had the same trend for yield sorghum intercropped with soybean. The actual yields of sorghum were $98.58 \%, 94.63 \%$ and $91.54 \%$ in the first season and $97.01 \%, 92.69 \%$ and $89.82 \%$ in the second season, respectively compared to sorghum pure stand. Similar the result by Tarhalkar and Rao (1975) have suggested that short sorghum less competition to intercropped legumes than taller sorghums.

Table 1. Effect of intercropping patterns on yield and its components of sorghum in the first and the second seasons.

\begin{tabular}{|c|c|c|c|c|c|c|}
\hline \multicolumn{7}{|c|}{ First season 2010} \\
\hline $\begin{array}{l}\text { Intercroping } \\
\text { patterns }\end{array}$ & $\begin{array}{l}\text { Plant height } \\
\text { (cm) }\end{array}$ & $\begin{array}{c}\text { Panicle } \\
\text { Length } \\
(\mathrm{cm})\end{array}$ & $\begin{array}{c}\text { Head } \\
\text { weight } \\
\text { (g) }\end{array}$ & $\begin{array}{c}\text { Grain } \\
\text { weight/ } \\
\text { head } \\
\text { (g) }\end{array}$ & $\begin{array}{l}100 \text { grain } \\
\text { weight } \\
\text { (g) }\end{array}$ & $\begin{array}{c}\text { Grain } \\
\text { yield/fad. } \\
\text { (ardab) }\end{array}$ \\
\hline $100+25 \%$ & 131.00 & 18.11 & 50.02 & 38.33 & 3.00 & 15.97 \\
\hline $100+50 \%$ & 133.56 & 16.89 & 48.78 & 36.78 & 2.85 & 15.37 \\
\hline $100+75 \%$ & 135.89 & 15.89 & 47.44 & 35.44 & 2.74 & 14.83 \\
\hline LSD 5\% & 1.55 & 0.71 & 0.28 & 0.28 & 0.05 & 0.15 \\
\hline Sorghum solid & 135.00 & 23.00 & 52.00 & 41.00 & 3.50 & 16.80 \\
\hline \multicolumn{7}{|c|}{ Second season 2011} \\
\hline $100+25 \%$ & 133.33 & 19.17 & 54.78 & 40.11 & 3.17 & 16.20 \\
\hline $100+50 \%$ & 134.89 & 18.00 & 50.55 & 38.78 & 2.94 & 15.48 \\
\hline $100+75 \%$ & 138.00 & 17.00 & 49.11 & 37.11 & 2.89 & 15.00 \\
\hline LSD 5\% & 1.29 & 0.30 & 0.40 & 0.40 & 0.03 & 0.48 \\
\hline Sorghum solid & 137.00 & 24.00 & 66.00 & 42.5 & 3.60 & 16.90 \\
\hline
\end{tabular}

b. Effect of three soybean cultivars on yield and its components of sorghum.

Data in Table (2) show that intercropped sorghum yields were $15.17,15.97$, and 15.00 in the first season and 15.35, 16.17 and $15.17 \mathrm{ardab} / \mathrm{fad}$ in the second season with soybean cultivars Giza 35, Giza 83 and Giza 111, respectively.

It is clear that highest values yield component of sorghum and grain yield/fad. with soybean Giza 83 cultivar (short plant soybean) and decreased with soybean Giza 111 cultivar (tall plant soybean). The percentage decreased of sorghum grain yield/fad. were $7.41 \%$ and $9.16 \%$ in the first and the second seasons, respectively as compared with sole crop. 
Table 2. Effect of intercropping three soybean cultivars on yield and its components of sorghum in the first and the second seasons.

\begin{tabular}{|c|c|c|c|c|c|c|}
\hline \multicolumn{7}{|c|}{ First season 2010} \\
\hline $\begin{array}{l}\text { Soybean } \\
\text { cultivars }\end{array}$ & $\begin{array}{l}\text { Plant height } \\
\text { (cm) }\end{array}$ & $\begin{array}{c}\text { Panicle } \\
\text { Length } \\
\text { (cm) }\end{array}$ & $\begin{array}{c}\text { Head } \\
\text { weight } \\
\text { (g) }\end{array}$ & $\begin{array}{c}\text { Grain } \\
\text { weight/ } \\
\text { head } \\
\text { (g) }\end{array}$ & $\begin{array}{l}100 \text { grain } \\
\text { weight } \\
\text { (g) }\end{array}$ & $\begin{array}{c}\text { Grain } \\
\text { yield/fad. } \\
\text { (ardab) }\end{array}$ \\
\hline G. 35 & 133.44 & 16.89 & 48.36 & 36.33 & 2.85 & 15.17 \\
\hline G. 83 & 135.56 & 17.67 & 50.11 & 38.46 & 3.01 & 15.97 \\
\hline G. 111 & 131.44 & 16.33 & 47.78 & 35.78 & 2.82 & 15.03 \\
\hline LSD $5 \%$ & 1.40 & 0.80 & 0.45 & 0.08 & 0.09 & 0.09 \\
\hline $\begin{array}{l}\text { Sorghum } \\
\text { Solid }\end{array}$ & 135.00 & 23.00 & 52.00 & 41.00 & 3.50 & 16.80 \\
\hline \multicolumn{7}{|c|}{ Second season 2011} \\
\hline G. 35 & 134.11 & 18.00 & 53.67 & 38.67 & 2.96 & 15.35 \\
\hline G. 83 & 137.00 & 19.00 & 51.44 & 40.11 & 3.20 & 16.17 \\
\hline G. 111 & 135.11 & 17.17 & 49.33 & 37.33 & 2.83 & 15.17 \\
\hline LSD $5 \%$ & 2.22 & 0.38 & 1.05 & 1.05 & 0.04 & 0.10 \\
\hline $\begin{array}{c}\text { Sorghum } \\
\text { Solid }\end{array}$ & 137.00 & 24.00 & 66.00 & 42.5 & 3.60 & 16.90 \\
\hline
\end{tabular}

c. Effect of the interaction between intercropping three soybean cultivars with sorghum on yield and yield components of sorghum.

Results in Table (3) head weight, grain weight per head, 100 grain weight and grain yield/fad. of sorghum were significantly in both seasons except plant height in the second season. The higher values yield components of sorghum were recorded for intercropping pattern $(100 \%$ sorghum+ $25 \%$ soybean) whereas the lowest values for intercropping pattern (100\% sorghum+ $75 \%$ soybean) with three soybean (Giza 35, Giza 83 and Giza 111 cultivars). The higher grain yield/fad. of sorghum show 16.4 and $16.67 \mathrm{ardab} / \mathrm{fad}$. observed with intercropping patterns $(100 \%$ sorghum $+25 \%$ soybean Giza 83 cultivar) in the first and the second seasons, respectively. This result may be due to the decreased in soybean density intercropped with sorghum from $75 \%$ up to $25 \%$ which decrease inter and intra specific competitive between plants for light, water and nutrients.

Table 3. Effect of the interaction between intercropping patterns and three soybean cultivars on yield and its components of sorghum in the first and the second seasons.

\begin{tabular}{|c|c|c|c|c|c|c|c|}
\hline \multicolumn{8}{|c|}{ First season 2010} \\
\hline $\begin{array}{c}\text { Intercropping } \\
\text { patterns }\end{array}$ & $\begin{array}{l}\text { Soybean } \\
\text { cultivars }\end{array}$ & $\begin{array}{c}\text { Plant } \\
\text { height } \\
(\mathbf{c m})\end{array}$ & $\begin{array}{c}\text { Panicle } \\
\text { Length } \\
(\mathrm{cm})\end{array}$ & $\begin{array}{c}\text { Head } \\
\text { weight } \\
\text { (g) }\end{array}$ & $\begin{array}{c}\text { Grain } \\
\text { weight/ } \\
\text { head } \\
\text { (g) }\end{array}$ & $\begin{array}{c}100 \\
\text { grain } \\
\text { weight } \\
\text { (g) }\end{array}$ & $\begin{array}{c}\text { Grain } \\
\text { yield/fad. } \\
\text { (ardab) }\end{array}$ \\
\hline $100+25 \%$ & & 131.00 & 18.00 & 50.07 & 38.00 & 2.93 & 16.00 \\
\hline $100+50 \%$ & G. 35 & 132.67 & 16.67 & 48.00 & 36.80 & 2.83 & 15.00 \\
\hline $100+75 \%$ & & 136.67 & 16.00 & 47.00 & 35.00 & 2.78 & 14.50 \\
\hline $100+25 \%$ & & 134.33 & 18.33 & 51.00 & 40.00 & 3.24 & 16.40 \\
\hline $100+50 \%$ & G. 83 & 136.00 & 18.00 & 50.33 & 38.33 & 2.96 & 16.00 \\
\hline $100+75 \%$ & & 136.33 & 16.67 & 49.00 & 37.00 & 2.83 & 15.50 \\
\hline $100+25 \%$ & & 127.67 & 18.00 & 49.00 & 37.00 & 2.84 & 15.50 \\
\hline $100+50 \%$ & G. 111 & 132.00 & 16.00 & 48.00 & 36.00 & 2.76 & 15.10 \\
\hline $100+75 \%$ & & 134.67 & 15.00 & 46.33 & 34.33 & 2.62 & 14.50 \\
\hline $\mathbf{L S}$ & $5 \%$ & 2.69 & NS & 0.48 & 0.48 & 0.23 & 0.40 \\
\hline & lid & 135.00 & 23.00 & 52.00 & 41.00 & 3.50 & 16.80 \\
\hline \multicolumn{8}{|c|}{ Second season 2011} \\
\hline $100+25 \%$ & G. 35 & 131.33 & 19.00 & 62.00 & 40.00 & 3.10 & 16.27 \\
\hline
\end{tabular}




\begin{tabular}{|c|c|c|c|c|c|c|c|}
\hline $100+50 \%$ & & 134.00 & 18.00 & 50.00 & 39.80 & 2.92 & 15.10 \\
\hline $100+75 \%$ & & 137.00 & 17.00 & 49.00 & 37.00 & 2.85 & 14.67 \\
\hline $100+25 \%$ & & 135.67 & 20.00 & 52.00 & 42.00 & 3.50 & 16.67 \\
\hline $100+50 \%$ & G. 83 & 136.33 & 19.00 & 52.33 & 40.33 & 3.07 & 16.17 \\
\hline $100+75 \%$ & & 139.00 & 18.00 & 50.00 & 38.00 & 3.03 & 15.67 \\
\hline $100+25 \%$ & & 133.00 & 18.50 & 50.33 & 38.33 & 2.90 & 15.67 \\
\hline $100+50 \%$ & G. 111 & 134.33 & 17.00 & 49.33 & 37.33 & 2.82 & 15.17 \\
\hline $100+75 \%$ & & 138.00 & 16.00 & 48.33 & 36.33 & 2.78 & 14.67 \\
\hline \multicolumn{2}{|c|}{ LSD 5\% } & NS & NS & 0.68 & 0.68 & 0.05 & 0.42 \\
\hline \multicolumn{2}{|c|}{ Solid } & 137.00 & 24.00 & 66.00 & 42.5 & 3.60 & 16.90 \\
\hline
\end{tabular}

2. Soybean

a. Effect of intercropping patterns on yield and yield components of soybean.

Results in Table (4) show that intercropping pattern (100\% sorghum+ $25 \%$ soybean) gave the highest values in numbers of branches, pods, seed and seed yield/plant and 100-seed weight in both seasons. The lower numbers of days and maturity was recorded intercropping pattern (100\% sorghum+ $75 \%$ soybean) in both seasons. Similar result is observed by Elmore and Jackobs (1984).
Seed yield /fad. of soybean had increased by increasing soybean density from $25 \%$ to $75 \%$ and $50 \%$ to $75 \%$ were recorded from 342.78 to 911.00 and 348.78 to $977.33 \mathrm{~kg} / \mathrm{fad}$. whereas 627.33 to 911.00 and 348.78 to $977.33 \mathrm{~kg} / \mathrm{fad}$. in the first and the second seasons, respectively. Similar result is observed by Olowe et al (2006) the low yield of intercropped soybean was apparently due to the shading effect of the vigorously growing local adapted sunflower variety.

Table 4. Effect of intercropping patterns on yield and its components of soybean in the first and the second seasons.

\begin{tabular}{|c|c|c|c|c|c|c|c|c|c|}
\hline \multicolumn{10}{|c|}{ First season 2010} \\
\hline $\begin{array}{l}\text { Intercropping } \\
\text { patterns }\end{array}$ & $\begin{array}{c}\text { No. of } \\
\text { days } \\
\text { to } \\
\text { flowering }\end{array}$ & $\begin{array}{c}\text { No. of days } \\
\text { to } \\
\text { maturity }\end{array}$ & $\begin{array}{l}\text { Plant } \\
\text { height } \\
(\mathbf{c m})\end{array}$ & $\begin{array}{c}\text { No. of } \\
\text { branches } \\
\text { /pl }\end{array}$ & $\begin{array}{l}\text { No. of } \\
\text { pods/pl }\end{array}$ & $\begin{array}{c}\text { No. of } \\
\text { seeds/pl }\end{array}$ & $\begin{array}{c}\text { Seed } \\
\text { yield/pl } \\
\text { (g) }\end{array}$ & $\begin{array}{c}100 \\
\text { seeds } \\
\text { weight } \\
(\mathrm{g}) \\
\end{array}$ & $\begin{array}{c}\text { Seed } \\
\text { yield } \\
\text { kg/fad. }\end{array}$ \\
\hline $100+25 \%$ & 33.67 & 112.11 & 101.67 & 1.81 & 23.28 & 58.21 & 8.79 & 15.20 & 342.78 \\
\hline $100+50 \%$ & 33.33 & 111.44 & 103.11 & 1.67 & 22.52 & 56.52 & 8.54 & 15.04 & 627.33 \\
\hline $100+75 \%$ & 33.00 & 110.44 & 104.44 & 1.60 & 21.82 & 54.70 & 8.31 & 14.98 & 911.00 \\
\hline LSD $5 \%$ & NS & 0.50 & 1.95 & 0.10 & 0.43 & 0.57 & 0.12 & 0.09 & 98.07 \\
\hline Solid G. 35 & 32.33 & 111.00 & 100.00 & 1.47 & 35.30 & 84.70 & 13.53 & 15.60 & 1378.67 \\
\hline Solid G. 83 & 29.67 & 98.00 & 86.67 & 1.90 & 30.37 & 73.40 & 10.03 & 13.67 & 992.00 \\
\hline Solid G. 111 & 36.33 & 121.00 & 106.67 & 2.00 & 39.63 & 92.17 & 16.16 & 17.47 & 1722.33 \\
\hline \multicolumn{10}{|c|}{ Second season 2011} \\
\hline $100+25 \%$ & 32.45 & 106.55 & 106.67 & 1.81 & 28.92 & 67.10 & 10.33 & 15.37 & 348.78 \\
\hline $100+50 \%$ & 32.00 & 105.78 & 108.89 & 1.76 & 28.07 & 65.82 & 10.03 & 15.26 & 683.11 \\
\hline $100+75 \%$ & 31.00 & 105.33 & 111.11 & 1.71 & 27.38 & 64.71 & 9.88 & 15.26 & 977.33 \\
\hline LSD $5 \%$ & 0.83 & 0.85 & 2.92 & NS & 0.32 & 0.63 & 0.10 & 0.07 & 26.65 \\
\hline Solid G. 35 & 31.00 & 108.00 & 100.00 & 2.30 & 35.67 & 85.13 & 13.73 & 16.13 & 1421.00 \\
\hline Solid G. 83 & 28.33 & 96.00 & 91.67 & 2.80 & 33.03 & 82.73 & 11.50 & 13.97 & 1165.00 \\
\hline Solid G. 111 & 36.00 & 119.33 & 118.33 & 2.57 & 40.53 & 95.63 & 16.63 & 17.33 & 1816.00 \\
\hline
\end{tabular}

b. Effect of three soybean cultivars on yield and its components of soybean.

Data presented in Table (5) show that all characters under study of soybean were significantly affected by soybean cultivar in both seasons except number of branches/plant in second season.
Giza 83 cultivar was the earliest in flowering and maturity in both seasons, while Giza 111 cultivar was the least in flowering and maturity in both seasons. Giza 111 cultivar had the tallest plants in both seasons, whereas plants of Giza 83 cultivar were the shortest in both seasons. Giza 111 cultivar 
produced the highest number of pods and seeds per plant and the heaviest weights of seed yield per plant and 100-seed in both seasons, while Giza 83 cultivar recorded the lowest values for these characters in both seasons.

The soybean yields were $783.33,655.44$ and $442.33 \mathrm{~kg} / \mathrm{fad}$. for Giza111, Giza 35 and Giza 83 cultivars, respectively in the first season, while their corresponding values in the second season were $849.67,650.00$ and $509.33 \mathrm{~kg} / \mathrm{fad}$., respectively.

The increase in seed yield of Giza 111 over Giza 35 and Giza 83 cultivars estimated 19.51 and $77.1 \%$ in the first season and 30.72 and $66.82 \%$ in the second season. The increase in yield of Giza 111 cultivar may be due to the increases in yield components comparing with the other two cultivars. Soybean cultivars showed similar behavior in case of solid. Similar the results by Pal et al (1992) and Muoneke et al (2007) had observed similar yield reductions in soybean intercropped with maize and sorghum and associated the yield depression to inter specific competition and the depressive effect of the cereals. Eybe (2010) the yield reduction of the intercropped soybean might be associated with inter specific competition between the intercrop components for growth resources (Light, water, nutrients, air etc.) and the depressive effects of sorghum.

Table 5. Effect of intercropping sorghum on three soybean cultivars on yield and its components of soybean in the first and the second seasons.

\begin{tabular}{|c|c|c|c|c|c|c|c|c|c|}
\hline \multicolumn{10}{|c|}{ First season 2010} \\
\hline $\begin{array}{l}\text { Soybean } \\
\text { cultivars }\end{array}$ & $\begin{array}{c}\text { No. of } \\
\text { days } \\
\text { to } \\
\text { flowering }\end{array}$ & $\begin{array}{c}\text { No. of } \\
\text { days } \\
\text { to } \\
\text { maturity }\end{array}$ & $\begin{array}{c}\text { Plant } \\
\text { height } \\
\text { (cm) }\end{array}$ & $\begin{array}{c}\text { No. of } \\
\text { branches } \\
\text { /pl }\end{array}$ & $\begin{array}{c}\text { No. of } \\
\text { pods/pl }\end{array}$ & $\begin{array}{c}\text { No. of } \\
\text { seeds/pl }\end{array}$ & $\begin{array}{c}\text { Seed } \\
\text { yield/pl } \\
(\mathrm{g})\end{array}$ & $\begin{array}{c}100 \\
\text { seeds } \\
\text { weight } \\
\text { (g) }\end{array}$ & $\begin{array}{c}\text { Seed } \\
\text { yield } \\
\text { kg/fad. }\end{array}$ \\
\hline G. 35 & 32.89 & 111.67 & 103.33 & 1.52 & 22.99 & 55.59 & 8.55 & 15.38 & 655.44 \\
\hline G. 83 & 29.67 & 100.22 & 91.67 & 1.73 & 20.43 & 53.13 & 7.02 & 13.21 & 442.33 \\
\hline G. 111 & 37.44 & 122.11 & 114.22 & 1.82 & 24.20 & 60.71 & 10.07 & 16.63 & 783.33 \\
\hline LSD $5 \%$ & 0.62 & 1.45 & 2.72 & 0.12 & 0.24 & 0.90 & 0.21 & 0.06 & 22.20 \\
\hline Solid G. 35 & 32.33 & 111.00 & 100.00 & 1.47 & 35.30 & 84.70 & 13.53 & 15.60 & 1378.67 \\
\hline Solid G. 83 & 29.67 & 98.00 & 86.67 & 1.90 & 30.37 & 73.40 & 10.03 & 13.67 & 992.00 \\
\hline Solid G. 111 & 36.33 & 121.00 & 106.67 & 2.00 & 39.63 & 92.17 & 16.16 & 17.47 & 1722.33 \\
\hline \multicolumn{10}{|c|}{ Second season 2011} \\
\hline G. 35 & 30.78 & 106.78 & 103.89 & 1.77 & 27.54 & 64.42 & 9.98 & 15.50 & 650.00 \\
\hline G. 83 & 28.67 & 95.33 & 98.33 & 1.78 & 26.24 & 63.60 & 8.73 & 13.72 & 509.33 \\
\hline G. 111 & 36.00 & 115.55 & 124.45 & 1.73 & 30.58 & 69.51 & 11.53 & 16.59 & 849.67 \\
\hline LSD $5 \%$ & 1.30 & 1.45 & 2.71 & NS & 1.66 & 0.85 & 0.26 & 0.12 & 24.32 \\
\hline Solid G. 35 & 31.00 & 108.00 & 100.00 & 2.30 & 35.67 & 85.13 & 13.73 & 16.13 & 1421.00 \\
\hline Solid G. 83 & 28.33 & 96.00 & 91.67 & 2.80 & 33.03 & 82.73 & 11.50 & 13.97 & 1165.00 \\
\hline Solid G. 111 & 36.00 & 119.33 & 118.33 & 2.57 & 40.53 & 95.63 & 16.63 & 17.33 & 1816.00 \\
\hline
\end{tabular}

c. Effect of the interaction between intercropping systems and three soybean cultivars on yield and its components of soybean.

Results in Table (6) indicate that number of pods and seeds/plant, seed yield/plant, 100-seed weight and seed yield/fad. were significantly affected by the interaction between intercropping systems and soybean cultivars in both seasons. Intercropping of soybean Giza 111 cultivar by $25 \%$ with $100 \%$ sorghum recorded the highest values for characters-ie plant height, number of branches, pods, seeds and seed yield per plant and 100-seed weight expect seed yield in both seasons, while, the lowest values for these characters showed with soybean Giza 83 cultivar when planted by $75 \%$. The highest values of seed yield/fad.were (1180.00 and $1262.00 \mathrm{~kg}$ in the first and the second seasons, respectively) with soybean Giza 111 cultivar when intercropped by $75 \%+100 \%$ sorghum. On the other hand the lowest values were obtained from soybean Giza 83 cultivar where sown by $25 \%+100 \%$ sorghum $(233.00$ and $285.33 \mathrm{~kg}$ ) in the first and the second seasons, respectively. 
Table 6. Effect of the interaction between intercropping patterns and three soybean cultivars on yield and its components of soybean in the first and the second seasons.

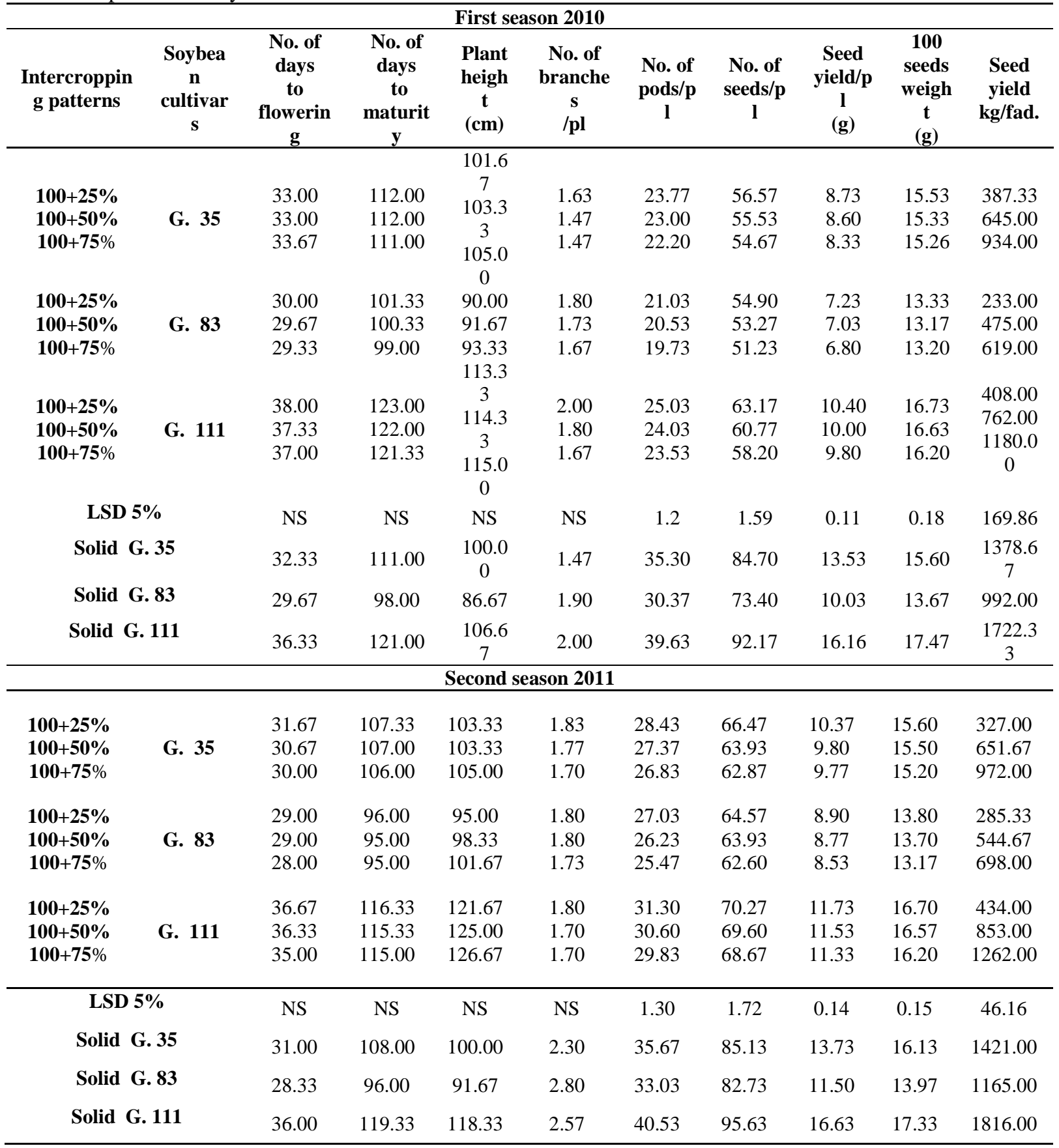

d. Competitive relationships and yield of interaction between intercropping systems and three soybean cultivars

1. Land equivalent ratio (LER):

Results in Table (7) show that the highest values LER 1.55 and 1.56 was observed intercropping pattern $(100 \%$ sorghum $+75 \%$ soybean Giza 111 cultivar), while the lowest 1.16 and 1.17 was observed intercropping pattern $(100 \%$ sorghum $+25 \%$ soybean Giza 111 cultivar) in the first and the second seasons, respectively. This result may be due to the increase soybean density from
$25 \%$ to $75 \%$ of pure soybean plants. Similar the results by Barik et al (1998) and Tajudeen (2010) indicated that mixed cropping increased the land equivalent ratio by $8 \%$ in 2 sorghum : 1 cowpea planting pattern over sole cropping, produced higher system productivity index, crowding coefficient and gross monetary return.

This indicates that LER increase 16 to $55 \%$ and 17 to $56 \%$ in the first and the second seasons, respectively more area would be required by the corresponding sole cropping systems. This result is similar to these by Barik et al (1998). 


\section{Land equivalent coefficient (LEC)}

The data in Table (7) show that LEC values greater than 0.25 of intercropping patterns expected intercropping patterns $(100 \%$ sorghum $+25 \%$ soybean Giza 83 and Giza 111 cultivars) in the first season and $(100 \%$ sorghum $+25 \%$ soybean Giza 35 and Giza 111 cultivars) in the second season. LEC values 0.59 and 0.60 which was greater than 0.25 was observed when intercropping patterns $(100 \%$ sorghum $+75 \%$ soybean Giza 111 cultivar) in both seasons. Similar result is observed by Adetiloye et al, (1983).

\section{Aggressivity}

The data in Table (7) show that soybean was dominant crop while sorghum was dominated under interaction between intercropping pattern $(100 \%$ sorghum $+75 \%$ soybean Giza 111 cultivar) and three soybean cultivars in both seasons. The aggressivity values different between dominant or dominated were observed when sorghum intercropped soybean
Giza 35 and Giza 83 cultivars. Similar result is observed by Ghosh et al (2006).

The greater $\mathrm{CR}$ values of sorghum were observed intercropping patterns (100\% sorghum $+75 \%$ soybean Giza 83 cultivar) in both seasons.

4. Monetary advantage index (MAI) and Monetary Equivalent Ratio (MER)

The highest MAI values 1978.85 and 2509.07 were observed intercropping pattern $(100 \%$ sorghum $+75 \%$ soybean Giza 111 cultivar) while the lowest values 562.48 and 749.41 were observed intercropping pattern (100\% sorghum $+25 \%$ soybean Giza 111 cultivar) in the first and the second seasons, respectively. The highest MER values 1.47 and 1.52 were observed the treatment (100\% sorghum $+75 \%$ soybean Giza 111 cultivar) in the first and the second seasons, respectively. MER values were greater than 1.00 thus signifying economic advantage of the intercropping system.

Table 7. Competitive relationships and yield advantage the interaction between intercropping patterns and three soybean cultivars in the first and the second seasons.

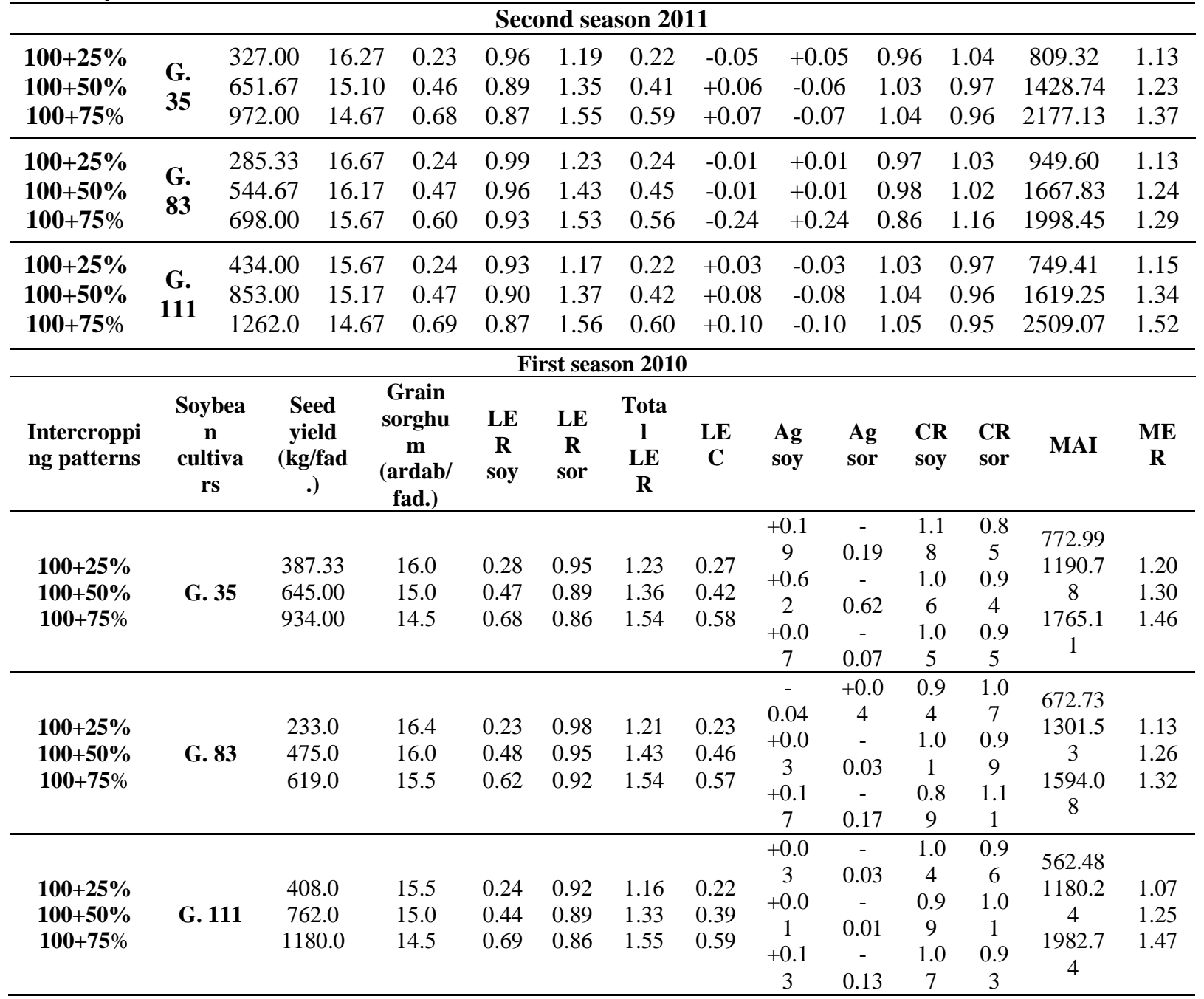


Reference

Abou Keriasha,M.A.; K.E.El-Habbak and S.A.A.Shams, (1993). Effect of intercropping soybean with same sorghum varieties on yield and yield components of the intercrops. Egypt. J. Appl. Sci., 8 (6):873-881.

Abdur Rashid, Himayatullah, K.Rehmatullah and M.A.Farooq, (2004). Effect of legume intercropping on sorghum production-pak. J. Agric. Sci., vol 41 (3-4):109-113.

Adetiloye, P.O. and A.A.Adekunle, (1989). Concept of monetary equivalent ratio and its usefulness in the evaluation of intercropping advantages Trop. Agric. 66: 337-341.

Adetiloye, P.O:, F.O.C.Ezedima and B.N.Okigbo, (1983). A land equivalent coefficient concept for the evaluation of competitive and productive interaction in simple to complex crop mixtures, Ecol. Modelling 19:27-39.

Aggarwal,P.K., S.P.Garrity, S.P.Liboon and R.A.Morris, (1992). Resource use and plant interactions in rice-mug bean intercrop. Agron. J. 84: 71-78.

Ahmad,G. D.Mehdi, A.S.Barat and R.mahmoud, (2010). Effect of maize-cowpea intercropping on light distribution, soil temperature and soil moisture in arid environment. Journal of food Agriculture Enviroment Vol 8 (1): 102-108.

Banik,P., T.Sasmal, P.K.Ghosal and D.K.Bagchi, (2000). Evaluation of mustard (Brassica compestrisvar toria) and legume intercropping under 1:1 and 2:1 row-replacement series system. J. Agron and Eropscience, 185: 9-14.

Barik,A.K., A.K.Mukherjee and B.K.Mandal, (1998). Growth and yield of sorghum and groundnut grown as sole and intercrops under different nitrogen regimes. Indian Journal of Agronomy 43 (1): 27-32.

Elmore,R.W. and J.A.Jackobs, (1984). Yield and yield components of sorghum and soybean of varying plant heights when intercropped Agron, J.76: 561-564.

El-Naim,A.M, B.A.Kilali, A.E.Hassan and M.F.Ahmed, (2013). Agronomic evaluation of sorghum and cowpea intercropped at different spatial arrangements. Journal of Renewable Agric., 1(2):11-16.

Eybe,O.M, (2010). Effects of plant density of intercropped soybean with tall sorghum on competitive obility of soybean an economic yield at Otob, Benue State Nigeria. J. of Cereals and oilseeds Vol 1 (1): 1-10.

Ghosh,P.K., (2004). Growth yield competition and economic of groundnut cereal faddan intercropping in the semi-arid tropics of India. Field crops Res., 88: 227-237.

Ghosh,P.K., M.C.Manna, K.K.Bandyopadhyag, Ajay, A.K.Tripattri, R.H.Wanjari, K.M.Hati, A.K.Misra, C.L.Acharya and A.Subba Rao,
(2006). Interspecific interaction and nutrient use in soybean sorghum intercropping system. Agron. J. 98: 1097-1108.

Haugguard-Nielsengh. Ambus,P. and E.S.Jensen, (2001). Interspecific competition Nuse and interference with weeds in pea-harley intercropping. Field crops Res, 70:101-109.

Langat,M.C., M.A.Okiror, J.P.Ouma and R.M.Gesimba, (2006). The effect of intercropping groundnut (Arachis hypogea L.) with sorghum (Sorghum bicolor L. Moench) on yield and cash income Agriculture Tropica El Subtropica Vol 39 (2): 87-93.

Li,L.;S.C.Yang;L.X.Li;F.S.Zhang and P.Christie, (1999). Interspecific complementary and competitive interaction between intercropped maize and faba bean. Plant Soil 212: 105-114.

Mc-Gillichrist,C.A., (1965). Analysis and Competition Experiments. Biometrics. 21: 975985.

MSTATC (1980). A Microcomputer Program of the Design Management and Analysis of Agronomic Research Experiments. Michigan State Univ., USA.

Muoneke,C.O.; M.A.O.Ogwuche and B.A.Kalu, (2007). Effect of maize planting density on the performance of maize/soybean intercropping system in guinea savanna agro ecosystem. Afr, J. Agric., Res., 2: 667-677.

Ofori,F. and W.R.Stern, (1987). Cereal-legume intercropping systems Adv. Agron 41: 41-90.

Oseni,T.O., (2010). Evaluation of sorghum- cowpea intercrop productivity in savanna agro-ecology using competition indices J. of Agric. Sci., vol (2) No (3): 229-234.

Olowe,V.I.O, J.A.Ajayi and A.S.Ogunbayo, (2006). Potential of intercropping soybeans (Glycine max (L.) Merrill) and cowpea (Vigna Unguiculata L.Waple) with sunflower (Helianthus annews L.) in the transition zone of south west Nigeria. Tropical Agric. Research Extension. 9: 91-102.

Pal,U.R., T.O.Oseni and J.C.Noman, (1992). Effect of component densities on productivity of soybean/maize, soybean/sorghum intercrop. J. Agron crop Sc., 170: 66-70.

Ress D.J., E.K.Njue, F.W.Makini and D.M.Mbugua, (1998). Participatory rural appraisals of farming systems of south west Kenya, 1995 and 1996. Kari, Kitale. 133p.

Singh,K. and J.S.Balyon, (2000). performance of sorghum (sorghum bicholor) plus legumes intercropping and nitrogen levels Indian J. Agron us (1):64-69.

Snedecor,G.W. and W.G.Cochran, (1988). Statistical Methods. $7^{\text {th }}$ Ed.Iowa State Univ. Press, Ames, Iowa, USA.

Spitters,C.J.T., (1983). An alternative approach to the analysis of mixed cropping experiment. 
Estimation competition effects. Netherlands, J. of Agric. Sci., 31:1-11.

Tajudeen,O.O., (2010). Evaluation of sorghumcowpea intercrop productivity in savanna agroecology using competition indices Journal of Agricultural Science, vol 2, No 3: 229-234.

Tariah,N.M. and T.A.T.Wahua, (1985). Effect of component population on yields and land equivalent ratios of intercropping maize and cowpea Field Crops Res., 12:81-89.

Tarhalkar,P.P. and N.G.P.Rao, (1975). Changing concepts and practices of cropping system. Indian Farming 25: 3-7.

Wahua,T.A.T. and D.A.Miller, (1978 a). Relative yield totals and yield components of intercropped sorghum and soybean. Agron. J. 70: 287-291.

Wahua, T.A.T and D.A.Miller, (1978 b). Effects of intercropping on soybean $\mathrm{N}$ Fixation and plant composition on associated sorghum and soybean. Agron. J. 70: 292-295.
Willey, R.W. (1979). Intercropping, its importance and research needs. part1: Competition and yield advantages. Field Crops Abst. 32: 1 -10.

Willey,R.W. and D.S.Osiru, (1972). Studies of mixtures of maize and beans (phaseolus vulgaris) with particular reference to plant population. J. of Agric. Sci., Cambridge plant 79:517-529.

Willey,R.W. and M.R.Rao, (1980). Competitive ratio for quantifying competition between intercrops. Exp. Agric. 16: 117-125.

Yilmaz,F.; M.Atak and M.Erayman, (2007). Identification of advantages of maize-legume intercropping over story cropping through competition indices in the East Mediterranean Region. Turk. J.Agric., 32: 111-119.

Zhang,F. and L.Li, (2003). Using competitive and facilitative interactions in intercropping systems enhances crop productivity and nutrient use efficiency. Plant and soil. 248: 305-312. 


\title{
تأثير تحميل فول الصويا مع الأرة الرفيعة على المحصول ومكوناته لكلا المحصولين
}

\author{
رأفت عايد جاد الله - "صموئيل برتى راغب \\ قسم بحوث التكثيف المحصولي - *قسم بحوث المحاصيل البقولية - معهد بحوث المحاصيل الحقلية - مركز البحوث الزراعية - الجيزة - \\ مصر \\ الملخص العربى
}

أجريت تجربة حقلية في محطة بحوث سدس بمحافظة بنى سويف خلال صيفى 2010 و 2011 لدراسة تحميل فول الصويا مع الذرة الرفيعة فى أنماط مختلفة من التحميل على المحصول ومكوناته لكلا المحصولين. وكان التصميم المستخدم هو القطع المنشقة مرة واحدة فى ثلاثة مكررات.

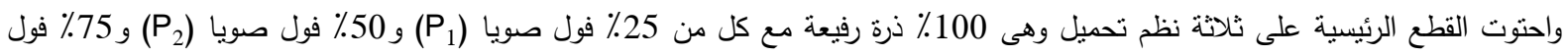

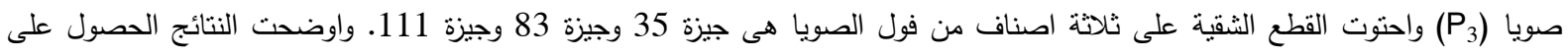
اعلى محصول للذرة الرفيعة بتحميله مع الصنف جيزة 83 بنظام 100٪ ذرة رفيعة + 25٪ فول الصويا ونقص بزيادة نسبة فول الصويا فى النظام

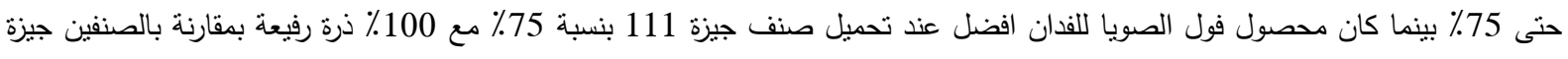

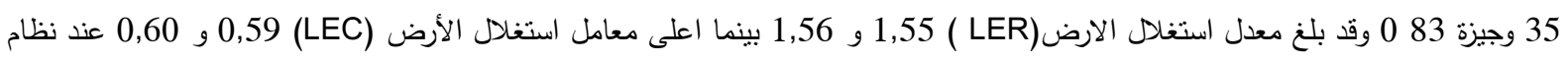
تحميل (100٪ ذرة رفيعة + 75٪ فول صويا صنف جيزة 111) فى العام الأول والثاني على التوالى0 هذا وقد اشارت قيم العدوانية الى ان فول الصويا كان هو السائد بينما الذرة الرفيعة هو المسود فى نظام تحميل الذرة الرفيعة مع فول الصويا صنف جيزة 1110 وسجلت أعلى قيم لمعدل

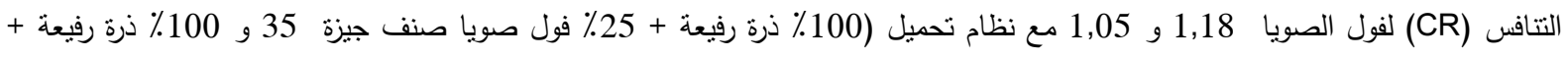

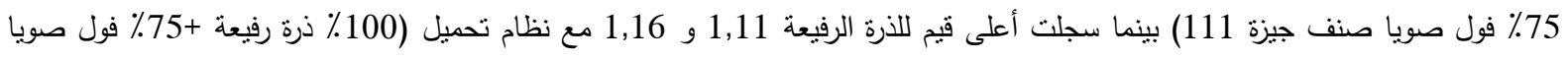
صنف جيزة 83). وبلغت أعلى قيم لدليل العائد الاقتصادى (MAI) (1978,85 و 2444,74 بينما أعلى قيم لمعدل العائد الاقتصادى (MER) 1,62 و 1,52 مع نظام تحميل (100\% الذرة الرفيعة + 75\% فول صويا صنف جيزة 111) فى العام الأول والثاني على التوالى. 